\title{
PROFIL POLA USAHA TAMBAK RAKYAT POLIKULTUR KEPITING BAKAU DAN IKAN BANDENG DI KELURAHAN PADANG SERAI PULAU BAAI KOTA BENGKULU
}

\section{Profile pattern of the community business of polyculture ponds mangrove crab and milkfish in the village Padang Serai Baai Island Bengkulu City}

\author{
${ }^{1}$ Citra Susantri Putri Sirait, ${ }^{2}$ Eko Sumartono \\ ${ }^{1}$ Mahasiswa Program Studi Agribisnis, Jurusan Sosial Ekonomi Pertanian Fakultas Pertanian \\ Universitas Bengkulu \\ 2Staff Pengajar Program Studi Agribisnis, Jurusan Sosial Ekonomi Pertanian Fakultas \\ Pertanian Universitas Bengkulu \\ Alamat : Jln WR Supratman Kandang Limun Kota Bengkulu \\ Email : eko_vixion@unib.ac.id
}

\begin{abstract}
This research was conducted at padang serai sub-district RT $04 R W 04$ in bengkulu city on february 2017. The objectives of this research were the farmer of mangrove crab and milkfish fish in Padang Serai Sub-District Bengkulu City. The location of the research was chosen by using purposive method and the respondents were chosen by using census method. The number of respondents were 5 people. Analytical methods used in this research were Descriptive analysis is case study. The results of the research Polyfish farming business of polyculture of mangrove crabs and bendeng fish in Padang Serai urban village when Prapasca business pattern starts from site selection, preparation of equipment, pond preparation by draining ponds, TSP and urea fertilizer, water filling then cage fertilization. Then the preparation of seeds, seeds used are seeds of mangrove crab and milkfish. Then carried out the maintenance by way of feeding and penaganan of pests in the form of the theft of business products. Harvesting products of mangrove crab and milkfish for milkfish only do total harvest while the mangrove crab is done by partial harvesting and total harvesting. Post-harvest handling is to do marketing of mangrove crabs to eat houses and for milkfish sold to pack rusan as pengumpul and to traders, the surrounding community who came to buy to the location.
\end{abstract}

Key word : polyculture, mangrove crab - milkfish, pre harvesting, harvest, pascaharvest

\section{PENDAHULUAN}

Indonesia merupakan negara kepulauan terbesar di dunia. Dengan 13.667 pulau, laut yang sangat luas dan panjang garis pantai lebih dari $81.000 \mathrm{~km}$, Indonesia memiliki potensi sumberdaya laut dan pantai yang sangat besar. Namun potensi tersebut juga memberi tantangan yang besar pula, yaitu bagaimana dapat memanfaatkannya secara optimal.(Bambang Agus Murtidjo, 1989)

Sumberdaya perikanan Indonesia merupakan aset pembangunan yang memiliki peluang besar untuk dijadikan salah satu sumber pertumbuhan ekonomi. Hal tersebut dapat dilihat dari kontribusi sektor perikanan terhadap produk domestik bruto (PDB) pertanian terbesar kedua setelah tanaman bahan makanan. Menurut BPS Indonesia, 2016 Sektor perikanan pada tahun 2013 berkontribusi sebanyak Rp 176.149,3 miliar atau 18.5 persen dari total PDB sektor pertanian. Oleh karena itu, sektor perikanan mengalami pertumbuhan ratarata yang yang paling tinggi dibandingkan dengan sektor lainnya yaitu 6.5 persen pada tahun 2009-2013. Dengan demikian sektor perikanan memiliki potensi yang besar untuk 
dikembangkan dalam memberikan kontribusi terhadap PDB Indonesia berupa peningkatan devisa.

Sektor perikanan di Indonesia ada 2 kelompok yaitu kegiatan perikanan tangkap dan perikanan budidaya. Menurut Ditjen perikanan tangkap dan ditjen perikanan budidaya, 2016 produksi perikanan tangkap di Indonesia pada tahun 2014 sebesar 6.484 .346 ton dan untuk perikanan budidaya sebesar 14.359 .129 ton. Melihat besarnya sumbangan sektor perikanan budidaya terhadap PDRB Indonesia maka dengan itu usaha perikanan budidaya merupakan usaha perikanan yang diharapkan untuk mampu memenuhi permintaan perikanan yang terus meningkat sejalan dengan meningkatnya populasi manusia di Indonesia.

Budidaya ikan di tambak bukanlah suatu yang baru bagi masyarakat indonesia, terutama yang bermukim di sekitar perairan umum (air tawar) dan pesisir pantai. Di Provinsi Bengkulu budidaya ikan tambak merupakan budidaya yang dikembangkan oleh masyarakat Bengkulu. Salah satunya Di kelurahan Padang Serai Kota Bengkulu masyarakatnya melakukan kegiatan tambak Rakyat polikultur Ikan kepiting-ikan bandeng. Pola polikultur ini merupakan pembudidayaan tambak yang pada satu lokasi/tempat dibudidayakan sekaligus dua jenis ikan yaitu, ikan kepiting bakau dan ikan bandeng. Pola budidaya ini dilakukan karena dapat mengefisienkan tempat, biaya serta meningkatkan produksi persatuan areal tambak dan juga dapat meningkatkan pendapatan masyarakat yang tinggal di Kelurahan Padang Serai. Maka melihat keadaan diatas diperlukan pengetahuan tentang pola usaha tambak rakyat polikultur ikan kepiting-ikan bandeng di Kelurahan Padang Serai Pulau Baii Kota bengkulu. Bagaimana prapasca panen usaha tambak rakyat ikan kepiting bakau-ikan bandeng di Kelurahan Padang Serai

Berdasarkan latar belakang yang dikemukakan di atas, maka yang menjadi permasalahan dalam penelitian ini adalah sebagai berikut : Bagaimana prapasca panen usaha tambak rakyat kepiting bakau dan ikan bandeng di kelurahan Padang Serai yaitu mulai dari pemilihan lokasi usaha tambak, Pembuatan tambak, Penyiapan alat dan perlengkapan, Peyiapan tambak, Penyiapan bibit dan penebaran bibit, pemeliharaan usaha tambak rakyat ikan kepiting bakau-ikan bandeng, pemanenanusaha tambak rakyat ikan kepiting bakau-ikan bandeng, dan pascapanen usaha tambak rakyat ikan kepiting bakauikan bandeng di kelurahan Padang Serai

Tujuan penelitian ini adalah mengetahui prapasca panen usaha tambak rakyat kepiting bakau dan ikan bandeng di kelurahan Padang Serai yaitu mulai dari pemilihan lokasi usaha tambak, Pembuatan tambak, Penyiapan alat dan perlengkapan, Peyiapan tambak, Penyiapan bibit dan penebaran bibit, pemeliharaan usaha tambak rakyat ikan kepiting bakau-ikan bandeng, pemanenan usaha tambak rakyat ikan kepiting bakau-ikan bandeng, dan pascapanen usaha tambak rakyat ikan kepiting bakau-ikan bandeng di Kelurahan Padang Serai

\section{METODOLOGI PENELITIAN}

\section{Lokasi dan Waktu Penelitian}

Penelitian dilakukan di Kelurahan Padang Serai, lokasi yang dipilih dalam penelitian ini ditentukan secara sengaja (purposive) Hal ini atas pertimbangan bahwa Kelurahan Padang Serai merupakan salah satu sentra budidaya kepiting bakau-ikan bandeng. Adapun waktu dalam proses pengambilan dan pengumpulan data serta informasi dilakukan selama pada bulan februari selama 21 hari.

\section{Metode Penelitian}

Metode tentang analisis biaya usaha, analisis produksi usaha dan analisis pemasaran usaha tambak rakyat polikultur kepiting-ikan bandeng menggunakan metode deskriptif 
dengan sifat studi kasus, yaitu studi dengan memusatkan perhatian pada suatu kasus secara intensif dan mendetail .

\section{Metode Penentuan Responden}

Metode pengambilan responden dilakukan dengan metode sensus. Menurut Singarimbun dan Effendi (1982), metode sensus adalah dimana seluruh polulasi diambil jadi responden. Dalam penelitian ini responden adalah seluruh petani tambak rakyat kepitingikan bendeng di kelurahan Padang Serai RT 08 RW 02, seluruh responden yang diambil sebanyak 5 orang.

\section{Metode Pengumpulan Data}

Data yang dikumpulkan dalam penelitian ini meliputi data primer dan data sekunder. Data primer diperoleh melalui pembagian kuisioner yang telah disiapkan dengan teknik wawancara langsung kepada penambak. Data sekunder diperoleh dari beberapa lembaga atau instansi pemerintah, seperti Badan Pusat Statistik (BPS), Departemen Kelautan dan Perikanan Pusat (DKP) Kota Bengkulu, serta berbagai literatur dan referensi yang mendukung agar relevan dengan penelitian yang sedang dilakukan

\section{Metode Pengolahan}

Pengolahan data dilakukan dengan menggunakan alat bantu yaitu kalkulator dan software komputer Microsoft Excel 2007 dan Microsoft word 2007

\section{HASIL DAN PEMBAHASAN}

\section{Karakteristik Petambak}

Karekteristik petambak yang diteliti sebanyak 5 orang petambak meliputi unsur umur, tingkat pendidikan formal, jumlah tanggungan keluarga, pengalaman usaha, jumlah petakan, dan luas tambak. Dapat dilihat pada tabel berikut:

Tabel 7. Identitas petambak di Kelurahan padang Serai Kecamatan Selebar kota Bengkulu tahun 2016

\begin{tabular}{|c|c|c|c|}
\hline No & Uraian & Rata-Rata & Persen(\%) \\
\hline \multirow[t]{3}{*}{1} & Umur (Tahun) & 47.6 & \\
\hline & $35-50$ & 3 & 60 \\
\hline & $51-65$ & 2 & 40 \\
\hline \multirow[t]{3}{*}{2} & Tingkat Pendidikan formal & 6.6 & \\
\hline & Tamat SD & 4 & 80 \\
\hline & Tamat SMP & 1 & 20 \\
\hline \multirow[t]{4}{*}{3} & Jumlah Tanggungan Keluarga (Orang) & 5 & \\
\hline & $2-3$ & 2 & 40 \\
\hline & $4-5$ & 1 & 20 \\
\hline & $6-7$ & 2 & 40 \\
\hline \multirow[t]{4}{*}{4} & Pengalaman Usaha Tambak(Tahun) & 4.4 & \\
\hline & $2-3$ & 2 & 40 \\
\hline & $4-5$ & 1 & 20 \\
\hline & $6-7$ & 2 & 40 \\
\hline \multirow[t]{3}{*}{5} & Jumlah Petakan Tambak (petak) & 3.6 & \\
\hline & $1-3$ & 2 & 40 \\
\hline & $4-6$ & 3 & 60 \\
\hline \multirow[t]{3}{*}{6} & Luas tambak (Ha) & 2.32 & \\
\hline & $0,5-3,4$ & 4 & 80 \\
\hline & $3,5-6,4$ & 1 & 20 \\
\hline
\end{tabular}

Sumber : Data Primer Diolah, 2017 
Berdasarkan tabel diatas, dapat dilihat bahwa rata-rata umur petambak pada penelitian ini adalah 47,6 tahun dengan kisaran umur 35-64 tahun. Berdasarkan data umur yang dikumpulkan, pada umumnya petambak berada pada usia produktif. Dimana usia ini seseorang mempunyai kemampuan yang lebih baik dalam berpikir dan bertindak umtuk merencanakan suatu kegiatan sehingga akan memberikan hasil yang maksimal jika dibandingkan dengan di bawah atau di atas umur produktif (Mubyarto,1987).

Pendidikan merupakan salah satu faktor yang menunjang keberhasilan petambak dalam mengelola tambak.Hal ini disebabkan karena tingkat pendidikan mempengaruhi peningkatan keterampilan, kecerdasan dan kepandaian petambak dalam memnelola usaha yang ditekuninya dengan sebaik-baiknya sehingga tujuan untuk meningkatkan pendapatan dapat dicapai (Mosher 1998). Diketahui bahwa 80\% petambak yang tamat SD, sedangkan 20\% lagi menamatkan pendidikan SMP. Berdasarkan hasil tersebut dapat dikatakan bahwa petambak dikelurahan Padang Serai rata-rata tamat SD.

Jumlah tanggungan keluarga berkaitan dengan berapa banyaknya tamggungan dari petambak kepiting bakau dan ikan bandeng. Tanggungannya rata-rata sebanyak 5 orang, yang memiliki jumlah tanggungan keluarga 2-3 orang sebesar $40 \%$ dan 5-6 orang sebesar $40 \%$ sedangkan yang memiliki jumlah tanggungan $4-5$ orang adalah sebesar $20 \%$. Jumlah tanggungan keluarga secara tidak langsung akan mempengaruhi motivasi pemilik tambak sebagai kepala keluarga untuk menjalankan dan memaksimalkan usaha sehingga dapat meningkatkan hasil produksi dan juga jumlah tanggunagan keluarga yang berada diusia produktif dapat bermanfaat sebagai persediaan tenaga kerja dalam keluarga.

Jumlah petakan dan luas tambak yang dimiliki oleh petambak rata-rata sebanyak 3,6 petakan yang memiliki petakan 1-3 petakan sebesar $40 \%$ dan yang memiliki petakan 4-6 petakan sebesar $60 \%$. Sedangkan untuk luas lahan yang dimiliki petambak di Kelurahan Padang serai rata-rata sebesar 2,32 Ha yang terdiri dari luas berkisaran 0,5-3,4 Ha sebanyak $80 \%$ dan luas yang berkisaran 3,5-6,4 sebanyak 20\%. Dalam usaha tambak ini jumlah petakan dan luas lahan sangat mempengaruhi

Dalam menjalankan usaha tambak di Kelurahan Padang Serai agar berhasil maka diperlukan pengalaman usaha un yang memiliki pengalaman usaha 2-3 tahun sebesar $40 \%$, yang memiliki pengalaman usaha $4-5$ tahun sebesar $20 \%$ dan yang memiliki pengalamn usaha 6-7 adalah sebesar $40 \%$ dalam menjalankannya. Pengalaman usaha yang dimiliki petambak dikelurahan Padang serai rata-rata 4,4 tahun.

\section{Pra-pasca panen}

Menurut soekartawi (1986) Pra-pasca panen adalah masa usaha sebelum melakukan pemanenan. Dalam usaha tambak ini sebelum masa panen terlebih dahulu melewati tahapan-tahapan prapasca panen dalam melakukan usaha Tambak rakyat kepiting bakau dan ikan bandeng dikelurahan padang serai Kota bengkulu. Adapun tahapan-tahapan prapasca panen pada usaha tambak rakyat polikultur kepiting bakau dan ikan bandeng di Kelurahan Padang Serai adalah sebagai berikut:

\section{Penentuan lokasi usaha tambak polikultur kepiting bakau dan ikan bandeng}

Lokasi usaha tambak rakyat polikultur kepiting bakau dan ikan bandeng berada di Kelurahan Padang Serai Kota Bengkulu. Lokasi tersebut dipilih karena merupakan daerah yang tidak padat penduduknya, sehingga lahan kosong masih tersedia dalam jumlah yang cukup luas dengan harga yang relatif murah dan juga di daerah itu telah tersedia tambak dalam bentuk penyewaan sehingga masyarakat yang tidak mempunyai modal yang lebih untuk membuat tambak bisa dengan melakukan penyewaan. Selain itu daerah/lokasi ini dekat dengan daerah lautan dan sungai sehingga pemasokan air untuk melakukan kegiatan bertambak tidak menemukan kesulitan. Namun dengan demikian hal yang tidak baik dari 
lokasi ini yaitu disaat terjadi pasang laut maka air yang ada didalam tambak akan meningkat pula sehingga dibutuhkan penanganan yang ekstra untuk mengontrol peningkatan air dan lokasi tersebut sangat sunyi dari pemukiman penduduk sehingga peluang untuk banyaknya maling kepiting bakau dan ikan bandeng sangat tinggi sehingga perlu dilakukan penjagaan ketat usaha tambak.

2. Pembuatan tambak

Setelah menentukan lokasi petambak melakukan pembuatan atau penyewaan tambak. Dalam usaha ini dari 5 responden 2 reponden yang membuat tambak sendiri dan 3 responden yang melakukan penyewaan tambak. Bentuk tambak yang diusahakan berupa petakan-petakan dengan berbagai ukuran. Tambak ini memiliki lantai tanah dan Ketinggian tambak dari dasar permukaan tanah sekitar 1-1,5 meter. Didalam tambak juga dilengkapi pipa paralon yang berguna untuk memasukkan air kedalam tambak dan mengeluarkan air dari dalam tambak. Tata letak petakan tambak satu dengan petakan tambak lainnya berdampingan satu dengan lainnya. Diluar tambak ada dibuat petakan sebagai tempat pemasok air yang nantinya digunakan dalam proses pengisian air kedalam tambak agar air selalu tersedia dan tempat untuk menetralkan air sebelum dimasukkan kedalam tambak

3. Penyiapan peralatan dan perlengkapan

Dalam usaha ini, setelah melakukan pembuatan atau penyewaan tambak, petambak melakukan penyiapan peralatan dan perlengkapan untuk dapat mendukung agar usaha tambak dapat berjalan dengan baik dan lancar. Adapun peralatan dan perlengkapan yang digunakan dapat dilihat pada tabel berikut :

Tabel 5. Penggunaan peralatan dan perlengkapan usaha tambak rakyat polikultur kepiting bakau dan ikan bandeng di Kelurahan Padang Serai

\begin{tabular}{llrrr}
\hline \multicolumn{1}{c}{ Uraian } & Jumlah & Satuan & Harga Beli \\
\hline $1 \quad$ Peralatan & & & \\
\hline \multicolumn{1}{l}{ Mesin pompa } & 1 & Unit & 3.700 .000 \\
& Pipa Paralon & 5,8 & Unit & 200.000 \\
Cangkul & 2 & Unit & 60.000 \\
Arco & 2 & Unit & 450.000 \\
Bubu & 24,4 & Unit & 30.000 \\
Saringan Halus & 9,4 & Meter & 10.000 \\
Saringan Kasar & 340 & Meter & 7.000 \\
Keranjang Panen/fiber & 4,6 & Unit & 450.000 \\
Jala Bandeng & 4,2 & Meter & 150.000 \\
Ember & 5,2 & Unit & 40.000 \\
Tali & 17,6 & Gulungan & 15.000 \\
Bola Lampu & 3,4 & Unit & 50.000 \\
\hline Perlengkapan & & & \\
\hline & Bangunan/Rumah Jaga & 1 & Unit & 45.000 .000 \\
Pembuatan instalasi listrik & 3,4 & Unit & 150.000 \\
\hline
\end{tabular}

Sumber : Data Primer Diolah, 2017

Dari tabel diatas peralatan yang gunakan petambak berupa mesin pompa, cangkul, arco, bubu, saringan halus, saringan kasar, fiber, jala bandeng, tali, ember, dan bola lampu. 
Mesin pompa dan pipa paralon digunakan dalam pengaturan air, yaitu dengan cara mengurangi dan mengisi tambak. Cangkul digunakan untuk mengangkat tanah-tanah yang terdapat ditambak dan memperdalam lubang tambak. Arco digunakan untuk mengangkut hasil panen dari tempat tambak kelokasi pengumpulan hasil tambak. Bubu digunakan untuk menangkap hasil panen dari kepiting bakau. Saringan halus digunakan sebagai penyaring untuk pipa paralon dan saringan kasar digunakan untuk membatasi tambak. Keranjang panen digunakan untuk meletakkan hasil panen Kepiting bakau dan ikan bandeng setelah dilakukan pemanenan. Ember digunakan untuk menaruh pakan sebelum dilakukan pemeberian pakan. Jala bandeng digunakan untuk menangkap hasil panen dari ikan bandeng. Tali digunakan untuk mengikat capit kepiting bakau setelah dilakukan pemanenan kepiting bakau dari tambak. Bola lampu digunanakan untuk menerang tambak diwaktu malam hari.

Dalam usaha tambak rakyat polikultur kepiting bakau dan ikan bandeng yang dilakukan di Kelurahan Padang serai untuk perlengkapan usaha terdiri dari biaya bangunan/rumah jaga dan pembangunan instalasi listrik. Bangunan/rumah jaga digunakan untuk tempat istirahat setelah melakukan pekerjaan menambak, tempak menyimpan peralatan, tempat menyimpan produk kepiting bakau dan ikan bandeng yang dipanen dan juga tempat istirahat sambil menjaga tambak. Pembagunan instalasi listrik digunakan untuk mengaliri listrik didaerah pertambakan agar bola lampu dapat dipasang untuk menerangi daerah tambak tersebut dimalam harinya.

\section{Penyiapan tambak}

Menurut Iskandar Kanna (2002) dalam penyiapan tambak ada beberapa sub kegiatan yang dilakukan yaitu: Perbaikan Konstruksi, Pengeringan tanah/tambak, Pemupukan, pengapuran dan pengisian air Sedangkan pada usaha tambak di Kelurahan Padang Serai sub kegiatan yang dilakukan dalam penyiapan tambak adalah sebagai berikut:

\section{a. Pengeringan tambak}

Tambak yang dibuat atau disewa jika masih terdapat air didalamnya maka dilakukan pengeringan menggunaan mesin pompa. Guna pengeringan tambak adalah untuk membunuh hama-hama yang ada didalam tambak yang nantinya akan mempengaruhi proses usaha tambak polikultur kepiting bakau dan ikan bandeng. Untuk memnggunakan mesin pompa dibutuhkan bensin dan oli. Penggunaan bensin dan oli dapat dilihat pada tabel berikut ini :

Tabel 6. Rata-rata penggunaan bensin dan oli pada saat pengeringan usaha tambak rakyat polikultur kepiting bakau dan ikan bandeng di Kelurahan Padang Serai

\begin{tabular}{llrr}
\hline No & Bensin dan oli & Satuan & Jumlah \\
\hline 1 & Bensin & Liter/Ha/UT & 20 \\
2 & Oli & Liter/Ha/UT & 4 \\
\hline
\end{tabular}

Sumber : Data Primer Diolah, 2017

Berdasarkan tabel 8 bahwa total rata-rata penggunaan bensin dan oli bakau dan ikan bandeng yang digunakan pada usaha ini, Untuk bensin berjumlah 20 liter/Ha/UT dengan harga Rp. 8000 /liter sedangkan untuk oli berjumlah 4 liter/Ha/UT dengan harga Rp. 35.000/ liter. 


\section{b. Pemupukan dengan pupuk TSP dan Urea}

Pemupukan dengan pupuk TSP dan urea merupakan proses pemberian bahan tambahan untuk meningkatkan kualitas dan mutu tanah yang ada ditambak dan menumbuhkan makanan alami bagi ikan bandeng dan kepiting bakau yang akan dipelihara nantinya sehingga produksinya nanti didapat dengan baik. Petambak kepiting bakau dan ikan bandeng di Kelurahan Padang Serai dari 5 responden petambak 2 responden yang melakukan pemupukan dengan pupuk TSP, Urea sedangkan 3 responden tidak melakukan pemupukan sama sekali. Pemupukan dengan pupuk TSP dan Urea dilakukan sebanyak satu kali per musim usaha(6 bulan), dengan sekali beri TSP sebanyak $50 \mathrm{~kg} / \mathrm{Ha}$ dan urea 100 $\mathrm{kg} / \mathrm{Ha}$. Pemupukan TSP dan Urea dilakukan pada awal usaha saat tambak masih keadaan kering, dengan menebarkan pupuk kepermukaan tambak yang kering yang belum di isi air dan diaduk-aduk dengan tanah permukan tambak agar menyatu dengan tanah tambak. Setelah melakukan pemupukan dengan TSP dan Urea kemudian dibiarkan selama 2 minggu. Adapun rata-rata jumlah pupuk TSP dan Urea yang digunakan pada usaha tambak polikultur kepiting bakau dan ikan bandeng di Kelurahan Padang serai dapat dilihat pada tabel berikut :

Tabel 7. Rata-rata penggunaan pupuk TSP dan urea pada usaha tambak rakyat polikultur kepiting bakau dan ikan bandeng di Kelurahan Padang Serai

\begin{tabular}{llrrr}
\hline No & Pupuk & Satuan & Jumlah & \\
\hline 1 & TSP & & $\mathrm{Kg} / \mathrm{Ha} / \mathrm{UT}$ & 20,67 \\
2 & Urea & $\mathrm{Kg} / \mathrm{Ha} / \mathrm{UT}$ & 41,33 \\
\hline
\end{tabular}

Sumber : Data Primer Diolah, 2017

Berdasarkan tabel 7 bahwa rata-rata penggunaan pupuk TSP pada usaha tambak rakyat polikultur kepiting bakau dan ikan bandeng di kelurahan Padang Serai berjumlah 20,67 kg/Ha/UT dengan harga Rp. 3000/kg dan untuk pupuk urea berjumlah 41,33 $\mathrm{kg} / \mathrm{Ha} / \mathrm{UT}$ dengan harga Rp.2100/kg

\section{c. Pegisian air}

Setelah 2 minggu dibiarkan lalu dilakukan pengisian air. Pengisian air kedalam tambak, dengan membuka dan mengatur pipa paralon sebangai tempat masukknya air kedalam tambak yang dilengkapi saringan halus dan juga dibantu dengan menggunakan mesin pompa. Pengisian dilakukan 2 tahap yaitu pengisian pertama air dimasukkan setengah tambak dulu dan selanjutnya ditambahkan lagi hingga hampir penuh. Untuk menggunakan mesin pompa dibutuhkan bensin dan oli. Penggunaan bensin dan oli dapat dilihat pada tabel berikut ini :

Tabel 8. Rata-rata penggunaan bensin dan oli pada saat pengisian air usaha tambak rakyat polikultur kepiting bakau dan ikan bandeng di Kelurahan Padang Serai

\begin{tabular}{llcr}
\hline No & Bensin dan oli & Satuan & Jumlah \\
\hline 1 & Bensin & Liter/Ha/UT & 20 \\
2 & Oli & Liter/Ha/UT & 4 \\
\hline
\end{tabular}

Sumber : Data Primer Diolah, 2017

Berdasarkan tabel 8 bahwa total rata-rata penggunaan bensin dan oli bakau dan ikan bandeng yang digunakan pada usaha ini, Untuk bensin berjumlah 20 liter/Ha/UT dengan harga Rp. 8000 /liter sedangkan untuk oli berjumlah 4 liter/Ha/UT dengan harga Rp. 35.000/ liter. 


\section{d. Pemupukan dengan pupuk kandang}

Setelah dilakukan pengisian air kemudian dilakukan pemupukan lagi menggunakan pupuk kandang. Pemupukan dengan pupuk kandang merupakan proses pemberian bahan tambahan untuk meningkatkan kualitas dan mutu tanah yang ada ditambak dan menumbuhkan makanan alami bagi ikan bandeng dan kepiting bakau yang akan dipelihara nantinya sehingga produksinya nanti didapat dengan baik. Petambak polikultur kepiting bakau dan ikan bandeng di Kelurahan Padang Serai dari 5 responden petambak 2 responden yang melakukan pemupukan dengan pupuk kandang sedangkan 3 responden tidak melakukan pemupukan kandang sama sekali. Dalam satu musim usaha tambak (6 bulan) pemupukan dengan pupuk kandang dilakukan sebanyak 12 kali dengan sekali beri jumlah pupuk kandang sebanyak $100 \mathrm{~kg} / \mathrm{Ha}$.

Pemupukan dilakukan dengan melubangi terlebih dahulu goni yang berisi pupuk kandang kemudian memasukkan langsung goni yang berisi pupuk kandang ke dalam tambak yang telah diisi air. Kemudian dibiarkan sekitar 2-4 minggu, bila pakan alami sudah mulai tumbuh tambak sudah dapat ditebari benih. Adapun rata-rata jumlah pupuk kandang yang digunakan pada usaha tambak polikultur kepiting bakau dan ikan bandeng di Kelurahan Padang serai dapat dilihat pada tabel berikut :

Tabel 9. Rata-rata penggunaan pupuk Kandang pada usaha tambak rakyat polikultur kepiting bakau dan ikan bandeng di Kelurahan Padang Serai

\begin{tabular}{cccc}
\hline No & Pupuk & Satuan & Jumlah \\
\hline 1 & Kandang & $\mathrm{Kg} / \mathrm{Ha} / \mathrm{UT}$ & 350 \\
\hline
\end{tabular}

Sumber : Data Primer Diolah, 2017

Berdasarkan tabel 7 bahwa rata-rata penggunaan pupuk kandang pada usaha tambak rakyat polikultur kepiting bakau dan ikan bandeng di Kelurahan Padang Serai berjumlah 480 $\mathrm{kg} / \mathrm{Ha} / \mathrm{UT}$ dengan harga Rp. 350/kg

\section{Penyiapan dan penebaran Bibit}

Benih yang digunakan dalam usaha ini yaitu benih kepiting bakau dan ikan bandeng. Benih kepiting bakau dibeli dari nelayan yang ada disekitar lokasi usaha. Benih kepiting ini dibeli dalam satuan kilogram, dalam satu kilo bisa didapatkan 3-4 ekor benih kepiting bakau dengan harga beli benih Rp. 25.000/kg. Benih kepiting bakau ini berwarna hitam kecoklatan dan masih memiliki bobot perekornya 3-4 ons. Sedangkan benih ikan bandeng dibeli dari Provinsi Lampung dengan satuan ekor, perekornya harga benih ikan bandeng Rp.250.

Pada usaha tambak ini penebaran benih kepiting bakau dilakukan sebanyak $40 \mathrm{kali}$ tebar dalam satu musim usaha(6 bulan), Jumlah sekali penebaran benih rata-rata $4 \mathrm{~kg} / \mathrm{Ha}$. Benih kepiting bakau yang dibeli langsung ditebarkan kedalam tambak. Untuk benih ikan bandeng setelah dibeli dilakukan adaptasi dulu didalam ember yang berisi air tambak sekirat 1-2 jam setelah itu dilakukan penyebaran ke dalam tambak. Menurut mujiman dan Suyanto (1987) penebaran benih udang windu untuk lahan 1 hektar sebesar 1000-10.000 ekor/musim sedangkan dikelurahan Padang Serai penebaran benih ikan bandeng satu musim usaha (6 bulan) hanya 1 kali tebar yaitu pada awal proses usaha saja. Penebaran bibit ikan bandeng rata-rata sebesar 8.000 ekor/Ha.

Dalam usaha polikultur kepiting bakau dan ikan bandeng penebaran benih kepiting bakau terlebih dahulu dilakukan lalu selanjutnya penebaran bibit ikan bandeng hal ini terjadi agar kepiting bakau terlebih dahulu dapat beradaptasi pada keadaan tambk dan juga karena bibit ikan bandeng harus terlebih dahulu dipesan sedangkan bibit kepiting bakau bisa dari nelayan langsung diperoleh harian. 
Tabel 10. Rata-rata penggunaan benih pada usaha tambak rakyat polikultur kepiting bakau dan ikan bandeng di Kelurahan Padang Serai

\begin{tabular}{cccc}
\hline No & Benih & Satuan & Jumlah \\
\hline 1 & Kepiting bakau & $\mathrm{Kg} / \mathrm{Ha} / \mathrm{UT}$ & 159,75 \\
2 & Ikan bandeng & Ekor/Ha/UT & $7.923,81$ \\
\hline
\end{tabular}

Sumber : Data Primer Diolah, 2017

Berdasarkan tabel 8 bahwa total rata-rata benih kepiting bakau dan ikan bandeng yang digunakan pada usaha ini, Untuk benih kepiting bakau berjumlah 159,75 Kg/ Ha/UT dengan harga Rp. 25.000/kg sedangkan untuk benih ikan bandeng berjumlah 7.923,81 ekor/Ha/UT dengan harga Rp. 250/ ekor.

\section{Pemeliharaan}

\section{a. Pemberian pakan}

Proses pemeliharaan kepiting bakau dan ikan bandeng, ketika benih ditebarkan, benih tersebut tidak langsung diberi pakan tetapi dibiarkan terlebih dahulu selama 1 minggu dan setelah itu diberi pakan 1 kali sehari yaitu pada sore hari saja. Petambak polikultur kepiting bakau dan ikan bandeng di Kelurahan Padang Serai dari 5 responden petambak 2 responden yang melakukan pemberian pakan ikan rucah, penggli halus dan alpet kasar sedangkan 3 responden lagi hanya memberikan pakan ikan rucah saja. Pemberian pakan ikan rucah selama satu musim usaha (6 bulan) dilakukan sebanyak 90 kali dengan satu kali tebar rata-rata sebesar $30 \mathrm{~kg} / \mathrm{Ha}$. Pemberian pakan pengli halus selama satu musim usaha (6 bulan) dilakukan sebanyak 15 kali dengan satu kali tebar rata-rata sebesar $4 \mathrm{~kg} / \mathrm{Ha}$. Pemberian pakan alpet kasar selama satu musim usaha (6 bulan) dilakukan sebanyak 45 kali dengan satu kali tebar rata-rata sebesar $4 \mathrm{~kg} / \mathrm{Ha}$. Penebaran pakan ikan rucah, pengli halus dan alpet kasar dilakukan menyebarkan kedalam petakanpetakan tambak.

Tabel 11. Rata-rata penggunaan pakan usaha tambak rakyat polikultur kepiting bakau dan ikan bandeng di Kelurahan Padang Serai

\begin{tabular}{llrr}
\hline No & \multicolumn{1}{c}{ Pakan } & Satuan & Jumlah \\
\hline 1. & Ikan Rucah & $\mathrm{Kg} / \mathrm{Ha} / \mathrm{UT}$ & 2.700 \\
2 & Pengli Halus & $\mathrm{Kg} / \mathrm{Ha} / \mathrm{UT}$ & 24 \\
3 & Pellet aplet kasar & $\mathrm{Kg} / \mathrm{Ha} / \mathrm{UT}$ & 72 \\
\hline
\end{tabular}

Sumber : Data Primer Diolah, 2017

Berdasarkan tabel 9 bahwa total rata-rata pakan kepiting bakau dan ikan bandeng yang digunakan pada usaha ini, Untuk pakan ikan rucah berjumlah $2.700 \mathrm{~kg} / \mathrm{Ha} / \mathrm{UT}$ dengan harga Rp. 2000/ kg, untuk pakan pengli halus berjumlah $24 \mathrm{~kg} / \mathrm{Ha} / \mathrm{UT}$ dengan harga Rp.10.000/kg dan untuk pakan pellet aplet kasar berjumlah $72 \mathrm{~kg} /$ musim dengan harga Rp.8000/kg.

b. Pemeliharaan dan penanganan Hama penyakit

Bentuk pemeliharaan yang dilakukan oleh petambak yaitu dengan selalu melakukan penjagaan selama 24 jam karena didaerah tersebut sangat banyak hama berupa manusia yang melakukan pencurian hasil produk di dalam tambak dengan cara memancing didalam tambak. Dan selain itu selalu mengontrol ketinggian air tambak agar air didalam tambak tidak terlalu tinggi yang dapat menyebabkan nantinya kepiting bakau dan ikan bandeng yang dipelihara keluar dari dalam tambak. 


\section{Pemanenan}

Menurut soekartawi (2002) Pemanenan Kepiting bakau sudah bisa dilakukan setelah 3-6.bulan. Pemanenan kepiting bakau dilakukan dengan 2 cara yaitu pemanenan sebagian dan pemanenan total. Pemanenan sebagian dilakukan sebanyak 40 kali dalam satu musim usaha (6 bulan) sekali panen rata-rata berjumlah 7-8 kg/Ha . Pemanenan mengunakan bubu sebagai alat panennya. Bubu yang telah diberi makanan pancingan ditenggelamkan kedalam tambak, dan dibiarkan sekita 2-3 jam setelah itu bubu ditarik kepermukaan, kepiting bakau yang tertangkap didalam bubu jika diperkirakan berukuran 7ons-1kg per ekor dipanen sedangkan yang masih berukuran kecil kurang dari 7ons dilepaskan kembali ke tambak. kepiting bakau diikat terlebih dahulu capitnya menggunakan tali rafiah lalu dimasukkan kedalam box dan kemudian langsung dijual kepada pembeli yang menjadi mitra petambak.

Pemanenan kepiting bakau dengan cara kedua yaitu pemanenan total yang dilakukan setelah satu musim usaha (6 bulan) bersamaan dengan pemanenan ikan bandeng. Pemanenan total kepiting bakau dan ikan bandeng dilakukan dengan menggunakan jala. Sebelum memanen air tambak terlebih dahulu dikuras dengan menggunakan mesin pompa agar lebih mempermudah dalam menjala kepiting bakau dan ikan bandeng. Setelah dijala ikan bandeng dan kepiting bakau yang didapat diangkat dan dilakukan pemilihan. Ikan bandeng dan kepiting bakau dengan kualitas A yang berkualitas B dan ikan bandeng tersebut dimasukkan kedalam keranjang panen/fiber Sedangkan kepiting bakau diikat terlebih dahulu capitnya menggunakan tali rafiah lalu dimasukkan kedalam box dan dijual kepada pembelinya.

Tabel 12. Rata-rata produksi usaha tambak rakyat polikultur kepiting bakau dan ikan bandeng di Kelurahan Padang Serai

\begin{tabular}{lllr}
\hline No & \multicolumn{1}{c}{ Uraian } & Satuan & Jumlah \\
\hline 1 & Kepiting Bakau & & 110 \\
\hline & Kualitas A & $\mathrm{Kg} / \mathrm{Ha} / \mathrm{UT}$ & 205,11 \\
& Kualitas B & $\mathrm{Kg} / \mathrm{Ha} / \mathrm{UT}$ & 113,38 \\
\hline 2 & Ikan Bandeng & & \\
\hline & Kualitas A & $\mathrm{Kg} / \mathrm{Ha} / \mathrm{UT}$ & 137 \\
& Kulaitas B & $\mathrm{Kg} / \mathrm{Ha} / \mathrm{UT}$ & \\
\hline
\end{tabular}

Sumber : Data Primer Diolah, 2017

Berdasarkan tabel 11 bahwa rata-rata produksi kepiting bakau yang di[panen berkualitas A yaitu dengan jumlah $110 \mathrm{~kg} / \mathrm{Ha} / \mathrm{UT}$ dijual dengan harga Rp. 100.000/kg dan kepiting bakau yang berkualitas B yaitu berjumlah 205,11 kg/Ha/UT dijual dengan harga Rp.85.000/kg sedangkan rata-rata produksi ikan bandeng yang dipanen berkualitas A yaitu dengan jumlah 113,38 kg/Ha/UT dijual dengan harga Rp.30.000/kg dan ikan bandeng yang berkualitas B yaitu berjumlah 137 kg/Ha/UT dijual dengan harga Rp.25.000/kg.

\section{Pasca Panen}

Menurut widyana dkk (2008) Pasca panen merupakan proses usaha yang dilakukan setelah melakukan proses pemanenan. Dalam usaha tambak rakyat kepiting bakau dan ikan bandeng di Kelurahan Padang Serai setelah melakukan pemanenan, hasil panen kemudian dimasukkan kedalam fiber / keranjang panen kemudian hasil panen tersebut langsung dijual kepada pembeli.

Produk kepiting bakau yang ada di Kelurahan Padang Serai rata-rata petambaknya menjualnya ke restaurant/rumah makan yang menjadi mitranya. Jumlah yang dijual utuk kepiting bakau sebanyak $110 \mathrm{~kg} / \mathrm{Ha} /$ tahun, harga jual yang ditetapkan oleh pihak 
restaurant/rumah makan untuk kepiting bakau kualitas A seharga 100.000/kg dan untuk kualitas B sebanyak 205,11 kg/Ha/tahun seharga 85.000/kg.

Untuk produk ikan bandeng yang ada di Kelurahan Padang Serai rata-rata petambak menjual hasilnya ke pengumpul didaerah itu yang benama pak ruslan. Alasan para petambak menjual kepada pak rusalan adalah karena tidak mau susah menjualnnya dan untuk menjalin kekerabatan. Kemudian pak ruslan telah mengumpulkan ikan bandeng menjual kepada pembeli yang lansung datang mengambil ke rumah bapak tersebut. Penjualan dilakukan dengan pembeli datang sendiri membeli hasil ikan bandeng ke Kelurahan Padang Serai.. Tata cara pembayaran yang dilakukan oleh pembeli yaitu dengan membayar secara cash produk kepiting bakau dan ikan bandeng yang telah dibeli.

\section{Kesimpulan}

\section{KESIMPULAN DAN SARAN}

Tambak rakyat polikultur kepiting bakau dan ikan bendeng di kelurahan Padang Serai pada saat Prapasca panen pola usahanya dimulai dari pemilihan lokasi yaitu lokasi yang dekat dengan laut dan sungai dan jauh dari pemukiman masyarakat, untuk pembuatan tambak usaha ada yang buat sendiri dan ada dengan melakukan penyewaan, sebelum melakukan usaha tambak dilakukan penyiapan peralatan dan perlengkapan guna mendukung proses berjalannya usaha setalah itu dilakukan penyiapan tambak dengan melakukan pengeringan tambak, pemupukan dengan TSP dan urea, pengisian air kemudian pemupukan kandang. Lalu penyiapan benih, benih yang digunakan yaitu benih kepiting bakau dan ikan bandeng. Kemudian dilakukan pemeliharaan dengan cara pemberian pakan dan penaganan dari hama berupa pencurian hasil produk usaha.

Pemanenan produk kepiting bakau dan ikan bandeng untuk ikan bandeng hanya melakukan pemanenan total sedangkan kepiting bakau dilakukan dengan pemanenan sebagian dan pemanenan total. Penanganan pasca penen yaitu dengan melakukan pemasaran kepiting bakau kerumah makan dan untuk ikan bandeng dijual kepada pak rusan sebagai pengunpul dan kepada pedagang, masyarakat sekitar yang datang membeli ke lokasi.

\section{Saran}

Usaha Polikultur kepiting bakau dan ikan bandeng memperluas lagi jaringan pemasaran kepiting bakau dan ikan bandeng agar lebih mempermudahkan dalam penjualan hasil kepiting bakau dan ikan bandeng yang nantinya dipanen dan pemberian pakan untuk usaha harus tepat waktu karena seperti yang diketahui kepiting bakau bersifat kanibal sehingga nantinya jika kelaparan dapat memangsa ikan bandeng yang ada didalam tambak.

\section{DAFTAR PUSTAKA}

Badan Pusat Statistik .2016. Produksi Perikanan Indonesia Tahun 2013.http:bps.go.id// Table Dinamis/view/id/1031. Diakses pada tanggal 2 september 2016

Ditjen perikanan tangkap dan ditjen perikan budidaya 2016. Produksi perikanan tangkaindonesia tahun 2014. Ditjen perikanan tangkap dan ditjen perikan budidaya :Indonesia

Kanna, Iskandar. 2002. Budidaya Kepiting Bakau (Pembenihan dan Pembesaran.Kanisius:Yogyakarta

Mubyarto. 1987. Pengantar Ekonomi Pertanian. LP3ES :Yogyakarta

Murtidjo, Bambang Agus. 1989. Tambak Air Payau (Budidaya Udang dan Bandeng). Kanisius : Yogyakarta

Mosher.A.T, Menggerakkan Dan Membangun Pertanian, Jakarta : C.V. Yasaguna 1966.

Mubyarto. 1987. Pengantar Ekonomi Pertanian. LP3ES :Yogyakarta 
Singarimbun, M dan Effendi, S. 1982. Metode Penelitian Survey. LP3ES. Jakarta.

Soekartawi.1986. Ilmu usahatani dan Penelitian Untuk Pengembangan Petani Kecil, UI-Press : Jakarta

Soekartawi.2002. Ilmu usahatani dan Penelitian Untuk Pengembangan Petani Kecil, UI-

Press : Jakarta

Widayana dkk.2008.Pengembangan Pola Usahatani Agribisnis Spesifik Lokasi di Pasang Surut.VolumeXIX No.3 ISSN.0853-5167. Fakultas Pertanian Universitas Sriwijaya. 